\title{
CHEVRON INSIDE THE REGULATORY STATE: AN EMPIRICAL ASSESSMENT
}

\author{
Christopher J. Walker*
}

\section{INTRODUCTION}

For three decades, scholars (as well as courts and litigants) have written thousands of articles (and opinions and briefs) concerning the impact of Chevron U.S.A. Inc. v. Natural Resource Defense Council, Inc. ${ }^{1}$ on judicial review of agency statutory interpretation. This should come as no surprise as Chevron is the most cited administrative law decision of all time. ${ }^{2}$ Little attention, however, has been paid to how Chevron and its progeny have actually shaped statutory interpretation inside the regulatory state. ${ }^{3}$ Indeed, as Jerry Mashaw observed nearly a decade ago, "virtually no one has even asked, much less answered, some simple questions about agency statutory interpretation." 4 Professor Mashaw concluded with a call for more

\footnotetext{
* Assistant Professor of Law, The Ohio State University Michael E. Moritz College of Law. Many thanks to Professors Nick Bagley, Kent Barnett, Jim Brudney, Ruth Colker, Tino Cuellar, Emily Hammond, Kristin Hickman, Jud Mathews, Deborah Merritt, Aaron Nielson, Guy Rub, Miriam Seifter, Peter Shane, and Peter Swire; to participants at the Big Ten Junior Faculty Conference and Fordham Law Review symposium Chevron at 30: Looking Back and Looking Forward; and, of course, to Professors Lisa Bressman and Abbe Gluck who shared their survey, methodology, and experiences from a similar project on congressional drafting. Thanks also to Professor Chris Holloman of The Ohio State University's Statistical Consulting Service for technical support; to Chris Larocco, James Mee, and Justin Nelson as well as Moritz librarian Matt Cooper for research assistance; and to the Center for Interdisciplinary Law and Policy Studies at The Ohio State University for funding. The author's utmost thanks go to the agency general counsels, deputies, and assistants who spent countless hours assisting with the empirical study and the 128 agency rule drafters who took the time to respond to the 195-question survey.
}

1. 467 U.S. 837 (1984).

2. See Peter M. Shane \& Christopher J. Walker, Foreword: Chevron at 30: Looking Back and Looking Forward, 83 FordHAM L. REV. 475, 475 \& n.2 (2014) (reporting citation counts for U.S. Supreme Court administrative law decisions).

3. Two contributors to this symposium explore other aspects of the role of Chevron inside the regulatory state. See Emily Hammond, Chevron's Generality Principles, 83 FORDHAM L. REV. 655 (2014) (exploring the effect of Chevron on agency behavior in rarely reviewed types of agency actions); Peter M. Shane, Chevron Deference, the Rule of Law, and Presidential Influence in the Administrative State, 83 FORDHAM L. REV. 679 (2014) (exploring the President's role in Chevron's deference regime). Another contribution, by contrast, provides a unique perspective on the impact-or, better said, lack thereof - of Chevron on state administrative law. See Aaron Saiger, Chevron and Deference in State Administrative Law, 83 FORDHAM L. REV. 555 (2014).

4. Jerry L. Mashaw, Norms, Practices, and the Paradox of Deference: A Preliminary Inquiry into Agency Statutory Interpretation, 57 ADMIN. L. REV. 501, 501-02 (2005); see also id. at $502 \mathrm{n} .2$ (reviewing literature). 
"[i]nquiry into the empirical realities of agency interpretive practice [to] provide a crucial window on these issues and an essential step in the assessment of the legitimacy of administrative governance." 5

As part of the Fordham Law Review symposium Chevron at 30: Looking Back and Looking Forward, this Essay answers Professor Mashaw's call to action and presents the findings of the first comprehensive empirical investigation into the effect of Chevron and related doctrines on how federal agencies interpret statutes they administer. ${ }^{6}$ The Essay draws on a larger, 195-question survey of federal agency rule drafters that covered a variety of topics related to agency statutory interpretation. ${ }^{7}$ The survey was modeled on Lisa Schultz Bressman and Abbe Gluck's pioneering study on congressional drafting, ${ }^{8}$ which Professor Gluck's contribution to this symposium further explores. ${ }^{9}$ The author administered the survey during a five-month period at seven executive departments (Agriculture, Commerce, Energy, Homeland Security, Health and Human Services, Housing and Urban Development, and Transportation) and two independent agencies (Federal Communications Commission and Federal Reserve). Responses were received from 128 agency officials whose primary duties included statutory interpretation and rulemaking (for a 31 percent response rate). Although concerns for confidentiality and deliberative process privilege imposed methodological limitations on the survey-including anonymity as to the individual respondent and the respondent's respective agency-the study's findings provide a crucial window into Chevron's influence on agency interpretive practices.

The Essay proceeds as follows. Part I provides an overview of the deference doctrines and the empirical study. Part I.A introduces the main deference doctrines and the theoretical work to date on how those doctrines may affect interpretive practices inside the regulatory state. This part focuses on Jud Mathews's deference lottery theory, which proposes that the

5. Id. at 537 .

6. For an overview of the symposium, see Shane \& Walker, supra note 2.

7. The full findings from the empirical study are reported elsewhere. See Christopher J. Walker, Inside Agency Interpretation, 67 STAN. L. REV. (forthcoming 2015) [hereinafter Walker, Inside Agency Interpretation], available at http://ssrn.com/abstract=2501716. The survey consisted of thirty-five main questions, with twenty-three questions containing three to thirty-three subquestions. In this Essay, those questions (and relevant subquestions) are cited. The survey is attached as an appendix to Walker, Inside Agency Interpretation, supra, and is available separately online. See Christopher J. Walker, Inside Agency Interpretation: Survey Appendix (Aug. 16, 2014) [hereinafter Walker, Survey Appendix], http://sstn.com/abstract $=2481631$

8. See Abbe R. Gluck \& Lisa Schultz Bressman, Statutory Interpretation from the Inside-An Empirical Study of Congressional Drafting, Delegation, and the Canons: Part I, 65 STAN. L. REv. 901 (2013) [hereinafter Gluck \& Bressman, Part I]; Lisa Schultz Bressman \& Abbe R. Gluck, Statutory Interpretation from the Inside-An Empirical Study of Congressional Drafting, Delegation, and the Canons: Part II, 66 STAN. L. REv. 725 (2014) [hereinafter Bressman \& Gluck, Part II]. Thanks again to Professors Bressman and Gluck for sharing their survey, methodology, and experiences from this congressional drafting study.

9. Abbe R. Gluck, What 30 Years of Chevron Teach Us About the Rest of Statutory Interpretation, 83 FORDHAM L. REV. 607 (2014). 
deference framework in administrative law be viewed through the gametheory lens of a lottery. ${ }^{10}$ This framework sheds considerable light on how varying standards of review may affect agency interpretive practices. Part I.A also discusses recent congressional efforts to instruct courts to apply Skidmore v. Swift \& Co. ${ }^{11}$ instead of Chevron on certain issues-a legislative invention Kent Barnett has coined "Chevmore codification" in his contribution to this symposium and elsewhere. ${ }^{12}$

The Chevmore codification and deference lottery theories both rest on empirical assumptions that federal agencies actually know and use these judicial deference doctrines when drafting regulations and that the agencies would draft regulations differently depending on which standard applied. In other words, if they knew the more deferential Chevron standard applied-as opposed to the Skidmore or de novo standards-the agencies would advance more aggressive statutory interpretations, and vice versa. Part I.B outlines the survey methodology to test these empirical assumptions and introduces the 128 agency rule drafters who responded to the survey. Parts II and III report the findings as to these two sets of empirical assumptions, respectively.

As discussed in Part II, the agency rule drafters surveyed were well aware of Chevron (at 94 percent) and Skidmore (at 81 percent), and indicated that Chevron (at 90 percent) and Skidmore (at 63 percent) played a role in their rule-drafting decisions. Although United States v. Mead Corp. ${ }^{13}$ another case crucial in the analysis, was not as well known by name (at 61 percent), the rule drafters confirmed that they understood the basic principles articulated in Mead-i.e., congressional authorization of rulemaking or formal adjudication (at 84 percent) and the agency's use of it (at 80 percent) affect whether an agency's interpretation receives Chevron deference. The rule drafters also reported that the Chevron presumption of delegation may have exceptions for certain types of ambiguities-some of which are consistent with existing judicial precedent and some not. For instance, fewer than half believed that Congress intends to delegate by ambiguity major policy questions (at 32 to 56 percent, depending on phrasing), preemption of state law (at 46 percent), or serious constitutional questions (at 24 percent).

As for the second set of empirical assumptions, the findings discussed in Part III reveal that the vast majority of rule drafters surveyed agreed or strongly agreed that they think about judicial review when drafting statutes (at 87 percent) and that their chances in court are better under Chevron than

10. Jud Mathews, Deference Lotteries, 91 TEX. L. REV. 1349 (2013); see also Christopher J. Walker, How to Win the Deference Lottery, 91 TEX. L. REV. 73 (2013) (responding to Mathews, supra). Indeed, Professor Mathews's framework played an important role in the development of the main part of the study presented in this Essay.

11. 323 U.S. 134 (1944).

12. Kent Barnett, Codifying Chevmore, 89 N.Y.U. L. REV. (forthcoming 2015) [hereinafter Barnett, Codifying Chevmore], available at http://ssm.com/abstract=2405016; Kent Barnett, Improving Agencies' Preemption Expertise within Chevmore Codification, 83 FORDHAM L. REV. 587 (2014) [hereinafter Barnett, Preemption and Chevmore].

13. 533 U.S. $218(2001)$. 
Skidmore or no deference (at 83 percent). Moreover, four in ten (38 to 43 percent) agreed or strongly agreed that federal agencies are more aggressive in their interpretive efforts if they know Chevron deference applies; another four in ten (40 to 45 percent) somewhat agreed. Part III then briefly explores the rule drafters' knowledge and use of various doctrines other than the deference standards that could affect how aggressive agencies are in their interpretive efforts.

This Essay provides a new and important window into the role of Chevron and its progeny inside the regulatory state. Based on the findings presented in this Essay, it would not be an understatement to conclude that thirty years of Chevron have saturated the federal agency rulemaking process. The rule drafters surveyed overwhelmingly indicated familiarity with and use of these doctrines in their statutory interpretation efforts, and many also indicated that federal agencies are more aggressive in their interpretive efforts if they are confident their interpretations will receive Chevron deference (as opposed to Skidmore or no deference at all).

\section{OVERVIEW}

To understand why Chevron and related doctrines may affect how federal agencies interpret statutes, one must first understand the current state of judicial review of agency statutory interpretation. Part I.A briefly presents the two dueling deference standards in a post-Chevron, post-Mead world, along with the empirical and theoretical work undertaken to date. Part I.B presents the survey methodology and the background on the 128 agency rule drafters who responded to the survey.

\section{A. The Doctrine: Dueling Deference Standards}

Administrative law today recognizes two main doctrines with respect to judicial review of agency statutory interpretations: Chevron and Skidmore.

The first is the familiar, thirty-year-old Chevron two-step approach we commemorate with this symposium. Under Chevron, a reviewing court must defer to an agency's interpretation of a statute it administers if the court finds, at Step One, that "the statute is silent or ambiguous" and then, at Step Two, that the agency's reading is a "permissible construction of the statute." 14 The court "need not conclude that the agency construction was the only one it permissibly could have adopted ... or even the reading the court would have reached if the question initially had arisen in a judicial proceeding." 15

The second is the much-older Skidmore standard, which, as Peter Strauss reminds us in his contribution, also celebrates its seventieth birthday this year. ${ }^{16}$ Unlike under Chevron where an agency's reasonable interpretation

14. Chevron U.S.A. Inc. v. Natural Res. Def. Council, Inc., 467 U.S. 837, 843 (1984).

15. Id. at 843 n.11.

16. Peter L. Strauss, In Search of Skidmore, 83 FordHAM L. Rev. 789, 789 (2014). As Professor Strauss notes, Chevron arguably just "universalized" a standard articulated in the same year as Skidmore in NLRB v. Hearst Publications, Inc., 322 U.S. 111 (1944). Strauss, 
of an ambiguous statute controls, Skidmore instructs the reviewing court to give the agency's interpretation "weight" based on "the thoroughness evident in [the agency's] consideration, the validity of its reasoning, its consistency with earlier and later pronouncements, and all those factors which give it power to persuade." 17

Courts and commentators often call Skidmore and Chevron "deference" doctrines, but reference to deference can obscure what is at stake in deciding which doctrine should apply to an agency's statutory interpretation. To capture the difference, Professor Strauss helpfully reframes these doctrines as "Chevron space" and "Skidmore weight."18 An agency receives Chevron space to fill in holes in statutes it administers because Congress empowered the agency to be "the authoritative interpreter (within the limits of reason) of such statutes." 19 Or, as Professor Strauss puts it, "the natural role of courts, like that of referees in a sports match, is to see that the ball stays within the bounds of the playing field and that the game is played according to its rules. It is not for courts themselves to play the game." 20 That is not the case with Skidmore weight, where Congress has not delegated space for agencies to be authoritative interpreters. Instead, Skidmore weight "addresses the possibility that an agency's view on a given statutory question may in itself warrant respect by judges who themselves have ultimate interpretive authority." 21

So even when it has no Chevron space, the agency retains the power to persuade based on its special expertise in statutory interpretation. Agencies often have comparative expertise based on their nationwide implementation of the statute and their involvement in drafting the statute. ${ }^{22}$ In sum, when framed in terms of Chevron space and Skidmore weight, it becomes clear what is at stake when an agency requests Chevron space:

supra, at 791-92; accord Thomas Merrill, The Story of Chevron: The Making of an Accidental Landmark, in ADMINISTRATIVE LAW STORIES 398 (Peter Strauss ed., 2006).

17. Skidmore v. Swift \& Co., 323 U.S. 134, 140 (1944).

18. Peter L. Strauss, "Deference" Is Too Confusing-Let's Call Them "Chevron Space" and "Skidmore Weight," 112 COLUM. L. REV. 1143, 1144-45 (2012); see also Mead, 533 U.S. at 247 (Scalia, J., dissenting) (explaining that Chevron "create[s] a space, so to speak, for the exercise of continuing agency discretion"); Skidmore, 323 U.S. at 140 (describing standard as "weight" based on "power to persuade").

19. Nat'l Cable \& Telecomms. Ass'n v. Brand X Internet Servs., 545 U.S. 967, 983 (2005). The author has explored elsewhere how Chevron and related doctrines are motivated by constitutional separation of powers values. See Christopher J. Walker, Avoiding Normative Canons in the Review of Administrative Interpretations of Law: $A$ Brand X Doctrine of Constitutional Avoidance, 64 ADMIN. L. REV. 139, 173-82 (2012) [hereinafter Walker, Brand X Constitutional Avoidance]; Walker, supra note 10, at 78; Christopher J. Walker, The Ordinary Remand Rule and the Judicial Toolbor for Agency Dialogue, 82 GEO. WASH. L. REV. (forthcoming 2014) [hereinafter Walker, The Ordinary Remand Rule], available at $\mathrm{http}: / / \mathrm{ssrn}$.com/abstract $=2242869$.

20. Strauss, supra note 18 , at 1145.

21. Id.

22. See id. Indeed, the agency rule drafters surveyed indicated their agencies play a substantial role in both the technical and the substantive drafting of statutes and even some role in the drafting of legislative history. See Walker, Inside Agency Interpretation, supra note 7 , at 34-36 \& fig. 6 (reporting survey findings on agencies' role in the legislative process). 
Win, and the agency becomes the authoritative interpreter (within the bounds of reason) of the statutory ambiguity. Lose, and the agency is relegated to the role of an expert witness that must rely on its powers to persuade the court to adopt the agency's preferred reading of the ambiguous statute. 23

The lack of Chevron space may result from either of the following: (1) Congress has not delegated interpretive authority to the agency; or (2) the agency has "cho[sen] not to exercise that authority, but rather to guide - to indicate desired directions without undertaking (as [it] might) to compel them." 24 The clearest evidence of such delegation is statutory authority for rulemaking or formal adjudication (and the agency's use of it). This was the basic takeaway from Mead: "a very good indicator of delegation meriting Chevron treatment [is] express congressional authorizations to engage in the rulemaking or adjudication process that produces the regulations or rulings for which deference is claimed." 25 In City of Arlington v. FCC, ${ }^{26}$ the U.S. Supreme Court clarified that it is not just "a very good indicator" but a dispositive one. ${ }^{27}$ But the Mead Court noted it had "sometimes found reasons for Chevron deference even when no such administrative formality was required and none was afforded."28

Shortly after Mead was decided, Thomas Merrill and Kristin Hickman labeled the Mead question about when Chevron space or Skidmore weight should apply as "Chevron step zero."29 Mead has since received extensive scholarly (and judicial) attention. Indeed, in their separate contributions to this symposium, Professors Hickman and Merrill are joined by Jack Beermann and Peter Strauss in chronicling that literature as well as debating the future of Chevron Step Zero after City of Arlington. ${ }^{30}$ Moreover, James Brudney's contribution relies on a dataset of 730 Supreme Court decisions to evaluate the use of Chevron and Skidmore in the workplace law context. $^{31}$ And Miriam Seifter's contribution rejects the call for a federalism exception at Chevron Step Zero. ${ }^{32}$ Accordingly, the substantial literature on Mead will not be further reviewed here.

23. Walker, supra note 10 , at 79.

24. Strauss, supra note 18 , at 1146.

25. United States v. Mead Corp., 533 U.S. 218, 229 (2001).

26. 133 S. Ct. 1863 (2013).

27. Id. at 1874 (holding that "the preconditions to deference under Chevron are satisfied because Congress has unambiguously vested the FCC with general authority to administer the Communications Act through rulemaking and adjudication, and the agency interpretation at issue was promulgated in the exercise of that authority").

28. Mead, 533 U.S. at 231. The Mead Court also confirmed that Skidmore weight applies when Chevron deference does not. See id. at 234-38 (reviewing Skidmore factors).

29. Thomas W. Merrill \& Kristin E. Hickman, Chevron's Domain, 89 GEo. L.J. 833, 836-37 (2001); Cass R. Sunstein, Chevron Step Zero, 92 VA. L. REV. 187, 207-11 (2006).

30. See Jack M. Beermann, Chevron at the Roberts Court: Still Failing After All These Years, 83 FordHAM L. REV. 731, $741-43$ (2014); Kristin E. Hickman, The Three Phases of Mead, 83 Fordham L. Rev. 527, 528-30 (2014); Thomas W. Merrill, Step Zero After City of Arlington, 83 FORDHAM L. REV. 731, 756-58 (2014); Strauss, supra note 16.

31. James J. Brudney, Chevron and Skidmore in the Workplace: Unhappy Together, 83 FORDHAM L. REV. 497, 498 (2014).

32. Miriam Seifter, Federalism at Step Zero, 83 FordHAM L. Rev. 633 (2014). 
The literature to date, however, has not explored empirically how Chevron, Mead, or Skidmore may affect statutory interpretation inside the regulatory state. And these questions are almost as equally undertheorized. As for theory, Jud Mathews's deference lottery framework is the main contribution. He explains that the interaction between Chevron space and Skidmore weight can be viewed as a "lottery" as that term is used in expected utility theory 33 -indeed, a compound lottery "whose prizes are other lotteries." 34 Agencies face a two-stage lottery when they adopt a statutory interpretation. The first is whether the court will review the interpretation for Chevron space or Skidmore weight. The second is whether the court will uphold the agency's interpretation under the deference standard selected in the first stage. ${ }^{35}$

The lottery's first stage arises from Mead's failure to provide clear guidance on when reviewing courts should apply Chevron space or Skidmore weight. ${ }^{36}$ Courts and commentators have bemoaned the uncertainty Mead introduced to administrative law. 37 And, as Professor Mathews has chronicled, ${ }^{38}$ the empirical studies to date have confirmed the existence of a deference lottery after Mead -with the leading studies on the Supreme Court jurisprudence by Bill Eskridge, Lauren Baer, and Connor Raso $^{39}$ and the leading study on the courts of appeals by Kristin Hickman

33. Mathews, supra note 10, at 1352; see also Melissa F. Wasserman, Deference Asymmetries: Distortions in the Evolution of Regulatory Law, 93 TEX. L. REV. (forthcoming 2015), available at http://ssrn.com/abstract=2416516 (modeling how deference regimes may push agency statutory interpretation in a pro-regulated-entity direction).

34. F.J. Anscombe \& R.J. Aumann, A Definition of Subjective Probability, 34 ANNALS MATHEMATICAL STAT. 199, 200 (1963) (defining compound lottery).

35. Mathews, supra note 10, at 1353; see also Orin S. Kerr, Shedding Light on Chevron: An Empirical Study of the Chevron Doctrine in the U.S. Courts of Appeals, 15 Y ALE J. ON REG. 1, 31 (1998) (finding agencies win 89 percent at Chevron Step Two).

36. See United States v. Mead Corp., 533 U.S. 218, 229-31 (2001).

37. See id. at 239-61 (Scalia, J., dissenting) (explaining the confusion Mead causes for courts in deciding whether Chevron applies); Thomas W. Merrill \& Kathryn Tongue Watts, Agency Rules with the Force of Law: The Original Convention, 116 HARV. L. REV. 467, 480 (2002) (asserting that Mead "provides little guidance to lower courts, agencies, and regulated parties about how to discern congressional intent in any given set of circumstances"); Thomas W. Merrill, The Mead Doctrine: Rules and Standards, Meta-Rules and MetaStandards, 54 ADMIN. L. REv. 807, 813 (2002) (describing Mead as "an undefined standard that invites consideration of a number of variables of indefinite weight"); Adrian Vermeule, Introduction: Mead in the Trenches, 71 GEO. WASH. L. REV. 347, 361 (2003) (arguing that Mead "inadvertently sent the lower courts stumbling into a no-man's land").

38. See Mathews, supra note 10, at 1362-72. Richard Pierce has similarly reviewed the existing empirical work, concluding that "the studies suggest that a court's choice of which doctrine to apply in reviewing an agency action is not an important determinant of outcomes in the Supreme Court or the circuit courts." Richard J. Pierce, Jr., What Do the Studies of Judicial Review of Agency Actions Mean?, 63 ADMIN. L. REV. 77, 85 (2011).

39. See William N. Eskridge, Jr. \& Lauren E. Baer, The Continuum of Deference: Supreme Court Treatment of Agency Statutory Interpretations from Chevron to Hamdan, 96 GEO. L.J. 1083 (2008); Connor N. Raso \& William N. Eskridge, Jr., Chevron as a Canon, Not a Precedent: An Empirical Study of What Motivates Justices in Agency Deference Cases, 110 Colum. L. REv. 1727 (2010); see also Peter H. Schuck \& E. Donald Elliott, To the Chevron Station: An Empirical Study of Federal Administrative Law, 1990 DUKE L.J. 984. 
and Matthew Krueger ${ }^{40}$ However, City of Arlington may have alleviated much of the uncertainty about whether Chevron or Skidmore applies in a given context by definitively declaring that Chevron always applies when Congress vests an agency with rulemaking or formal adjudication authority and the agency uses that authority to promulgate its interpretation. ${ }^{41}$

Regardless whether there is enough Chevron Step Zero uncertainty to make the first stage a meaningful lottery, viewing the deference regime through the lottery framework can help us think critically about how varying standards of review may affect agency behavior and how courts (or Congress) can modify the standards to influence agency behavior. For instance, Professor Mathews argues that having some uncertainty about which standard applies - as opposed to always applying Chevron - actually "offers a more flexible tool for shaping agency behavior" because "[a] deference lottery can encourage a rational agency to choose an interpretation that lies somewhere between the safest and the most adventurous version that the agency can hope to get away with." 42 For instance, Professor Mathews argues, "paradoxically, increasing the scrutiny an agency will receive under Skidmore can actually encourage an agency to adopt a less faithful interpretation of the statute." 43 That is because if Skidmore is difficult to satisfy, "the expected benefit is higher from selecting an interpretation the agency prefers and 'betting it all' on the Chevron lottery." 44 Moreover, if Skidmore were too easy on the agency, the agency would have less incentive to adopt a more faithful statutory interpretation because it would almost always win the second-stage deference lottery. Simultaneously tightening the Skidmore and Chevron lotteries to make it harder for the agency to win may be just as effective at encouraging more faithful interpretation. ${ }^{45}$

The deference lottery is not just a game for courts and agencies to play. Although not explored by Professor Mathews, Congress could also intervene to change one or both of these lotteries. Indeed, as Professor Barnett notes in his contribution to this symposium, Congress has actually done that in at least one instance. In the Dodd-Frank Wall Street Reform and Consumer Protection Act, ${ }^{46}$ Congress directed courts to review for Skidmore weight any decision to preempt state law made by the Office of the Comptroller of the Currency (OCC). ${ }^{47}$ Like Professor Mathews,

40. See Kristin E. Hickman \& Matthew D. Krueger, In Search of the Modern Skidmore Standard, 107 Colum. L. REV. 1235 (2007); see also Lisa Schultz Bressman, How Mead Has Muddled Judicial Review of Agency Action, 58 VAND. L. REV. 1443 (2005).

41. City of Arlington v. FCC, 133 S. Ct. 1863, 1874 (2013); accord Seifter, supra note 32 , at 640 .

42. Mathews, supra note 10 , at 1354 .

43. Id.

44. Id. at $1354-55$.

45. See id. at 1386-87.

46. Pub. L. No. 11-203, 124 Stat. 1376 (2010) (codified as amended in scattered sections of $7,12,15,18,22,31,42$ U.S.C.).

47. Barnett, Preemption and Chevmore, supra note 12, at 587; see also 12 U.S.C. $\S 25 \mathrm{~b}(\mathrm{~b})(5)(\mathrm{A})(2012)$ ("A court reviewing any determinations made by the Comptroller regarding preemption of a State law ... shall assess the validity of such determinations, 
Professor Barnett goes on to theorize how this change in the deference lottery should affect agency behavior, asserting that Chevmore codification can encourage the agency to, among other things, develop more expertise and engage in more public participation. ${ }^{48}$ Congressional modification of the deference regime would likely have a greater impact on agency decision making than just a judicial modification as the congressional directive would be reinforced by the courts on judicial review. ${ }^{49}$

Until now, however, whether judicial or legislative tinkering with the deference standard would actually affect agency behavior seemed plausible in theory but unknown in fact. There are at least two sets of untested empirical assumptions: (1) whether federal agencies know and consider these deference doctrines when interpreting statutes; and (2) whether federal agencies interpret statutes differently if they know their interpretation will receive Chevron space or Skidmore weight. ${ }^{50}$ Parts II and III of this Essay, respectively, attempt to shed some empirical light on these questions. First, however, Part I.B explains the underlying study's methodology.

\section{B. The Empirical Study: Methodology and Background}

The findings reported in this Essay are drawn from a larger empirical study on agency statutory interpretation. ${ }^{51}$ As mentioned in the Introduction, that study was modeled on the 171-question survey conducted by Professors Bressman and Gluck on congressional drafting. ${ }^{52}$ Most of the questions relevant to this Essay, however, were not included in the Bressman and Gluck study. Indeed, nearly half (97 of 195) of the questions in this study dealt with administrative law doctrines, whereas the Bressman and Gluck study included forty-five questions on those topics. ${ }^{53}$

Similarly, their methodology had to be adapted to the federal agency context where the pool of potential respondents is spread across hundreds of

depending upon the thoroughness evident in the consideration of the agency, the validity of the reasoning of the agency, the consistency with other valid determinations made by the agency, and other factors which the court finds persuasive and relevant to its decision.").

48. See Barnett, Preemption and Chevmore, supra note 12, at 605.

49. See id. at 605-06.

50. A third and related set of assumptions concerns whether the standard of review significantly affects the likelihood of agency success in court. Professor Barnett has noted this elsewhere - reviewing the studies to date that suggest the standard does not matter-and concluded that if the studies are correct, the "so-called Skidmore penalties and Chevron rewards lose some force." Barnett, Codifying Chevmore, supra note 12, at 63. Those empirical assumptions lie outside the scope of this study, but for purposes of understanding the effect of Chevmore codification, they also may not shed too much light. As Professor Barnett has noted, the more important question is whether federal agencies' interpretive practices differ when Chevron or Skidmore applies: "Therefore, even if it is only a myth that Chevron and Skidmore lead to different results [in court], that myth [if believed by the federal agencies] has purchase on agencies and Congress." Id. at 65.

51. This part presents an abbreviated version of the study's methodology set forth in greater detail in Part I of Walker, Inside Agency Interpretation, supra note 7. When possible, please refer and cite to the longer version of the methodology description.

52. See Gluck \& Bressman, Part I, supra note 8, at 919-24.

53. Id. at 992. 
federal agencies and offices, and adequate access to that pool would require official approval from the agency and not just the individual respondent. Accordingly, over the span of nine months, the author reached out to officials at every executive department, over eighty agencies and offices within those departments, and a dozen or so independent agencies. Ultimately, various agencies and offices at seven executive departments and two independent agencies agreed to participate. ${ }^{54}$ As a condition for participation, the agencies required that the survey be anonymous as to both the respondent and the respondent's agency and that it be conducted online as opposed to the in-person approach of the Bressman and Gluck study.

The online survey consisted of thirty-five questions, many of which had multiple subquestions for a total of 195 questions. ${ }^{55}$ The agency point

54. Some departments limited the survey population to particular agencies or offices, but within those populations the survey was sent to all officials identified as having experience in statutory interpretation and rulemaking. A total of forty-one offices, agencies, and divisions were included in the survey, with the breakdown by department and independent agency as follows (total population sent the survey in parentheses):

- U.S. Department of Agriculture (55): Office of General Counsel and eighteen USDA agencies and offices (e.g., the Food Safety and Inspection Service, the Forest Service, and the Office of Risk Assessment and Cost-Benefit Analysis);

- U.S. Department of Commerce (13): Office of General Counsel, Commerce Bureau of Industry and Security, and the U.S. Patent and Trade Office;

- U.S. Department of Energy (eighteen): Office of General Counsel;

- U.S. Department of Homeland Security (55): Office of General Counsel, Federal Emergency Management Agency, Transportation Security Administration, U.S. Customs and Border Protection, and U.S. Coast Guard;

- U.S. Department of Health and Human Services (146): Food and Drug Administration (FDA) and the Public Health Division;

- U.S. Department of Housing and Urban Development (10): Office of General Counsel;

- U.S. Department of Transportation (81): Office of the Secretary, the National Highway Traffic Safety Administration, the Federal Motor Carrier Safety Administration, the Federal Railroad Administration, the Pipeline and Hazardous Material Safety Administration, the Federal Transit Administration, the Federal Aviation Administration, and the Federal Highway Administration;

- Federal Communications Commission (16): Office of General Counsel; and

- Federal Reserve (17): Legal Division. Unlike the other agencies surveyed, to reduce the workload on the Legal Division, the Federal Reserve only sent the survey to a seventeen-person subset of potential rule drafters - though the point-of-contact chose that subset based on which agency officials are most engaged in rule drafting on a regular basis.

55. Walker, Survey Appendix, supra note 7. Because many of the questions build on prior questions and in light of concerns about incomplete surveys, see infra note 58 , the thirty-five main questions were asked in chronological order; subquestions were randomized within each main question to minimize response-order effects. See, e.g., Jon A. Krosnick \& Duane F. Alwin, An Evaluation of a Cognitive Theory of Response-Order Effects in Survey Measurement, 51 PUB. OP. Q. 201, 201-19 (1987); William S. Sekely \& Vicki L. Blakney, The Effect of Response Position on Trade Magazine Readership and Usage, 34 J. AD. RES. 53, 53-59 (1994). There are methodological costs to not fully randomizing the survey in that the order may affect the answers, though such effects are typically more of an issue with attitudinal studies (which this is not). See generally HOWARD SCHUMANN \& STANLEY PRESSER, QUESTIONS AND ANSWERS IN ATTITUDE SURVEYS: EXPERIMENTS ON QUESTION FORM, WORDING, AND CONTEXT (1981). Moreover, Professors Bressman and Gluck found 
persons sent the survey via email to the populations of agency officials identified as having experience in statutory interpretation and rulemaking, encouraging but not requiring them to respond. ${ }^{56}$ In total, 411 such agency officials received the survey, and 128 agency officials responded for a 31 percent response rate..$^{57}$ Of the respondents, ninety-eight ( 77 percent) answered each and every question..$^{58}$ The survey also allowed the respondents to make additional comments on most questions; the data set includes 345 such comments, including sixty-nine comments in response to the administrative law questions.

So who are these agency rule drafters that responded to the survey? All are career civil servants as opposed to political appointees. ${ }^{59}$ And all but eleven are lawyers..$^{60}$ Nearly two-thirds have worked at a federal agency in a capacity that includes some rulemaking work for at least five years. ${ }^{61}$

no response-order effects when they scrambled the questions in their related congressional drafting survey. See Abbe R. Gluck \& Lisa Schultz Bressman, Statutory Interpretation from the Inside: Methods Appendix, 65 STAN. L. Rev. OnLINE 1, 12 \& n.45 (2013), available at http://www.stanfordlawreview.org/print/article/statutory-interpretation-inside-methods-

appendix. To help the reader account for any response-order effects, the Essay references the relevant question number being discussed-abbreviated as " $Q$ "- with the survey reproduced as Walker, Survey Appendix, supra note 7.

56. The surveying phase took place over the course of five months at the various agencies; the agency contacts followed up with the populations via email roughly two weeks after the initial invitation and then a final reminder about two weeks after that. Of the 128 respondents, only one answered "no" to the first question about whether the respondent is "currently working, or [has] worked within the last two years, in a general counsel office, legal department, or other rulemaking office in a federal agency AND that [the respondent] had experience in statutory interpretation and rulemaking in that employment," and thus did not respond to the survey beyond the background questions.

57. The anonymous nature of the survey limits the ability to calculate a response rate by agency or department. However, because the survey was rolled out at different times at each agency, the data collected confirm that at least some individuals in all of the population pools responded (as opposed to being predominated by one department or independent agency). That said, there is no way to assess with precision whether the response rate differs across the agencies contacted. As a result, it is possible that nonresponse bias is strong within a single agency due to cultural or other factors. Moreover, the FDA requested that its rule drafters have the option to indicate that they work at the FDA, so the first question was modified to allow for the respondents to voluntarily so indicate. Of the 128 responses, twenty indicated that they worked at the FDA. The size of the FDA rule-drafter population that received the survey was seventy, so assuming all FDA respondents self-identified the FDA response rate was 27 percent, which is in line with the overall 31 percent response rate.

58. The answers from respondents who did not fully complete the survey are included in the findings. A sizeable number of respondents (thirty) provided only partial responses. This rate might indicate the survey was intimidating to individuals who did not possess a strong grasp of the concepts being discussed, resulting in undersampling of less knowledgeable individuals at the agencies. Another plausible explanation is that some respondents tired of the 195-question survey, as there does not appear to be any pattern about when respondents stopped answering questions. Because the main thirty-five questions were not randomized (though the subquestions were), supra note 55, the undersampling can be taken into account and the total number of respondents " $\left(\mathrm{n}={ }_{-}\right)$" will be included for each question-abbreviated as " $\mathrm{Q}\left(\mathrm{n}={ }^{\prime}\right)$ ".

59. Q2 $(\mathrm{n}=128)$. As discussed in notes 55 and 58 supra, " $\mathrm{Q}$ " refers to the question number in Walker, Survey Appendix, supra note 7, and " $\mathrm{n}=$ " refers to the number of rule drafters who answered that question. The data set is on file with the author.

60. Q6 $(n=126)$.

61. Q3 ( $\mathrm{n}=128)$. 
About four in ten have had a role in the drafting process of at least a dozen rules, with another 15 percent in the seven to eleven range, 25 percent in the three to six range, and the rest (16 percent) in the zero to two range. ${ }^{62}$ One respondent, for instance, indicated involvement in "over 500 rulemaking actions"; another indicated that "[j]ust in the past 7 years, it has been 80 rules between proposed rules, interim rules, and final rules"; and a third said they were "too numerous to count." 63 Moreover, 38 percent are over the age of forty-five, 51 percent are between thirty-one and forty-five, and the remaining 11 percent are between twenty-two and thirty. ${ }^{64}$ Four in ten (42 percent) respondents took a course in law school on legislation, statutory interpretation, or statutory drafting, whereas half (49 percent) did not. ${ }^{65}$ Only one in four respondents have taken such a course other than in law school-many via continuing legal education or government training programs. ${ }^{66}$

Before turning to the findings in Parts II and III, it is important to underscore that, as with any survey that attempts to understand human behavior, caution should be taken so as to avoid reading too much into the rule drafters' responses. Despite the fact that all rule drafters at these agencies were sent the survey, not every executive department, much less every federal agency, agreed to participate. So the generalizability of the survey findings is limited by whether the surveyed agencies constitute a fair representation of the administrative state overall. ${ }^{67}$ Indeed, because of the methodological limitations imposed by the participating agenciesincluding the anonymous nature of the survey and a limited sampling of agencies $^{68}$ - the Essay errs on the side of caution and presents a descriptive

62. $\mathrm{Q} 4(\mathrm{n}=128)$.

63. Q4, cmts. 3, 10, 11. The specific comments are numbered in the data set. For ease of reference, those numbers are cited herein.

64. Q5 $(n=126)$.

65. Q6 $(n=126) ; Q 7(n=126)$. The survey also asked what year the respondent graduated from law school (Q6), and such results are similar to the age ranges. Id. Although outside the ambitions of this Essay, it would be interesting to compare whether when one graduated from law school affects one's views on Chevron and related doctrines.

66. $\mathrm{Q} 8(\mathrm{n}=126)$.

67. See generally Floyd J. FOWLER, SURVEY RESEARCH Methods (5th ed. 2014) (discussing the broad scope of biases that need to be considered).

68. These, of course, are not the only methodological limitations. For instance, there is always the possibility of social desirability bias. Respondents might feel that they should indicate greater familiarity with the interpretive tools (and greater use of them) than they actually possess (and do), since they might view it as the most appropriate way to conduct their jobs. The tendency to modify answers in this way arises from two sources, termed "self-deception" and "other-deception." See generally H.A. Sackeim \& R.C. Gur, SelfDeception, Self-Confrontation, and Consciousness, in 2 CONSCIOUSNESS AND SELFREGUlation: ADVANCES IN RESEARCH AND THEORY 139 (G.I. Schwartz \& R.D. eds., 1978). In this study, attempts were made to minimize social desirability bias. As for otherdeception, the survey was completely anonymous and taken online outside the presence of an interviewer. As for self-deception, the survey was designed to ask about the same interpretive tools in different ways, by name and by principle. See Anton J. Nederhof, Methods of Coping with Social Desirability Bias: A Review, 15 EUR. J. Soc. PsYCHOL. 263 (1985). As discussed, supra notes 58-67, there may also be issues with selection bias, incomplete surveys, nonrandomization of main questions order, and other biases that the 
picture of these particular 128 rule drafters. (The Bressman and Gluck study took the same approach ${ }^{69}$ ) That said, this study is the most extensive inquiry into actual agency interpretive practices to date, and the raw numbers shed considerable light on the influence of Chevron and related doctrines on agency statutory interpretation.

\section{LOOKING BACK: THE DEFERENCE DOCTRINES IN AGENCY STATUTORY INTERPRETATION}

As discussed in Part I.A, the deference lottery and Chevmore codification theories both assume that agencies know about Chevron space and Skidmore weight, that these standards play a role in agencies' drafting decisions, that agencies think about judicial review when drafting statutes, and that the agencies may interpret a statute differently based on which standard applies. Part II reports the survey findings related to the former two assumptions concerning doctrine familiarity and reported use in rule drafting. ${ }^{70}$ Part III then presents the findings as to the latter two assumptions about how Chevron and related doctrines may shape agency interpretive behavior.

\section{A. Awareness and Use by Name: Chevron the Big Winner}

With respect to Chevron, Mead, Skidmore, and Auer/Seminole Rock, ${ }^{71}$ the rule drafters were asked whether they were familiar by name with these "interpretive doctrines related to how much deference courts will accord federal agency decisions" and whether "these doctrines play a role in [their] drafting decisions." 72 Figure 1 depicts their responses to these questions. ${ }^{73}$

study has attempted to minimize but nonetheless cannot be completely controlled or measured through the methodology utilized.

69. See Gluck \& Bressman, Part I, supra note 8, at 923.

70. The findings reported in Part II are discussed in greater detail-albeit with a different focus-in Part IV of Walker, Inside Agency Interpretation, supra note 7, whereas the findings discussed in Part III have not been previously reported.

71. Auer/Seminole Rock deference instructs courts to give an agency's interpretation of its own regulation "controlling weight unless it is plainly erroneous or inconsistent with the regulation." Bowles v. Seminole Rock \& Sand Co., 325 U.S. 410, 414 (1945); accord Auer v. Robbins, 519 U.S. 452, 461 (1997). This standard lies outside of the scope of the Essay but is noted for comparison purposes. The agency rule drafters were also asked about Curtiss-Wright deference, which is a "super-strong deference to executive department interpretations in matters of foreign affairs and national security." Eskridge \& Baer, supra note 39, at 1100; see United States v. Curtiss-Wright Exp. Corp., 299 U.S. 304, 320 (1936). Only 6 percent indicated any awareness of this doctrine by name, with 2 percent indicating the doctrine played a role in their rule-drafting decisions. Q17(e) $(n=109) ; \mathrm{Q} 18(\mathrm{e})(\mathrm{n}=109)$.

72. Q17; Q18.

73. Q17(a)-(d) $(n=109) ; Q 18(a)-(d)(n=109)$. 


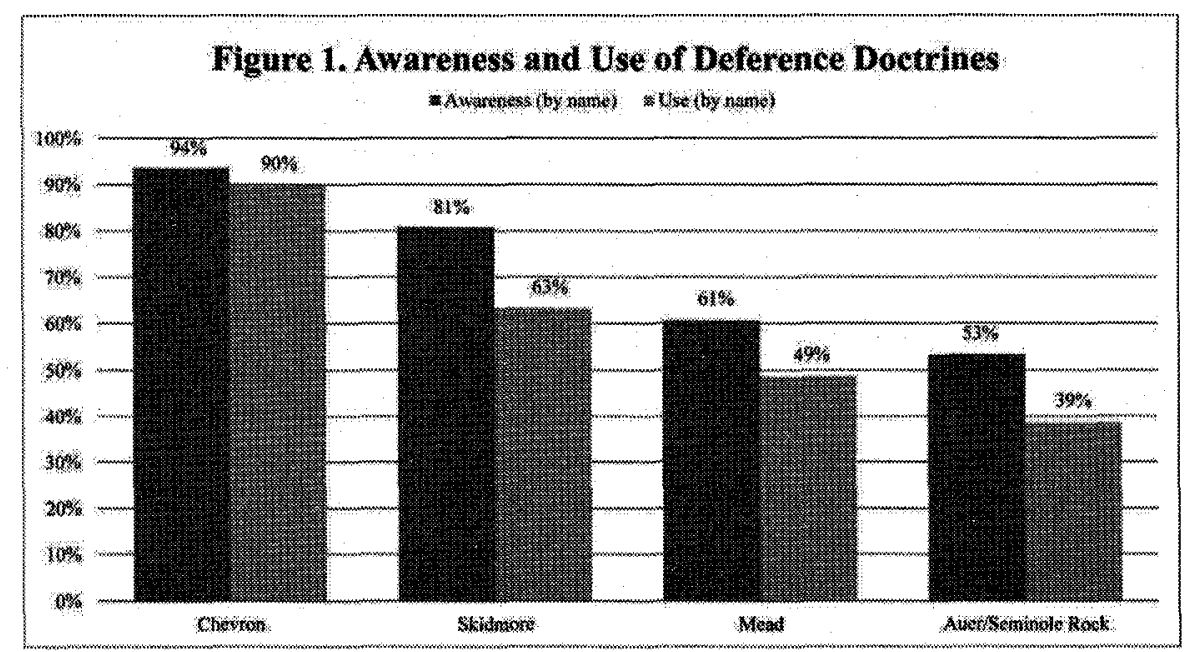

As Figure 1 illustrates, Chevron was the big winner at 94 percent awareness, followed by Skidmore at 81 percent, Mead at 61 percent, and Auer/Seminole Rock at 53 percent. ${ }^{74}$ The results were similar for their reported use in rule drafting, though reported use was less than awareness: Chevron at 90 percent, Skidmore at 62 percent, Mead at 49 percent, and Auer/Seminole Rock at 39 percent. ${ }^{75}$ About one in ten (11 percent) rule drafters, however, indicated that none of these doctrines played a role in their drafting decisions. ${ }^{76}$

Indeed, Chevron was the clear winner of the entire study. Among all twenty-two interpretive tools tested in the survey, Chevron was the most known by name (at 94 percent) and most reported as playing a role in rule drafting (at 90 percent). The next most known tools were: the ordinary meaning canon (at 92 percent); Skidmore (at 81 percent); and the presumption against preemption of state law (at 78 percent). ${ }^{77}$ The tools most reported after Chevron as playing a role in rule drafting were: the whole act rule (presumption of consistent usage throughout statute) (at 89 percent); the ordinary meaning canon (at 87 percent); Mead (by concept) (at 80 percent); noscitur a sociis (associated-words canon) (at 79 percent); and legislative history (at 76 percent). ${ }^{78}$

Moreover, without referring to Chevron by name, the rule drafters were asked whether they agreed with the following Chevron restatement: "If a statute is ambiguous and the agency's construction is reasonable, a court must accept the agency's construction of the statute, even if the agency's reading differs from what the court believes is the best statutory interpretation." 79 About four in five strongly agreed (46 percent) or agreed

74. Q17(a)-(d) $(\mathrm{n}=109)$.

75: Q18(a)-(d) $(\mathrm{n}=109)$.

76. Q18(f) $(\mathrm{n}=109)$.

77. Walker, Inside Agency Interpretation, supra note 7, at 18-20 \& fig.1.

78. Id. at $18-20$ \& fig.2.

79. Q16(b). 
(38 percent), and another 11 percent agreed somewhat. Only 5 percent disagreed at all, with one rule drafter indicating strong disagreement ${ }^{80}$ In sum, the overwhelming majority of rule drafters surveyed indicated that they knew, used, and agreed with Chevron space and to a somewhat lesser extent knew and used Skidmore weight when drafting rules.

\section{B. Awareness by Concept: Mead the Big Winner}

Although the rule drafters knew (61 percent) and used (49 percent) Mead by name less than Chevron or Skidmore, Mead was a big winner when rule drafters were asked about the underlying principles-i.e., that congressional authorization for, and agency use of, rulemaking or formal adjudication are strong indicia of congressional delegation to agencies. ${ }^{81}$ To measure Mead awareness, the rule drafters were asked whether eight different factors "affect whether Chevron deference (as opposed to Skidmore deference or no deference) applies to an agency's interpretation of an ambiguous statute it administers." 82 Table 1 presents their answers to this question. ${ }^{83}$

The leading factors the rule drafters reported to affect if Chevron applies were the two Mead principles: whether Congress authorized the agency to engage in rulemaking and/or formal adjudication ( 84 percent), and whether the agency promulgated the interpretation via rulemaking and/or formal adjudication ( 80 percent), followed by whether the agency has expertise relevant to interpreting the statutory provisions at issue (79 percent) ${ }^{84}$ Fewer than half agreed with the other factors listed: the interpretation sets forth the bounds of the agency's jurisdiction (46 percent), longstanding nature of agency's interpretation ( 43 percent), its contemporaneous nature (20 percent), its furtherance of uniform administration of law (18 percent), and the agency's political accountability ( 9 percent). ${ }^{85}$

80. $Q 16(b)(n=104)$. Because this question asks about the rule drafters' agreement with particular statements, those who indicated they did not know are not included in the number of respondents or the percentage calculation. No doubt the following comment reflected the strong dissenter's perspective: "'a court MUST ACCEPT the agency's interpretation'? Uh, no. Maybe they should, but after all, it is courts that review agency interpretations and not the other way around." Q16, cmt. 3.

81. United States v. Mead Corp., 533 U.S. 218, 229-31 (2001).

82. Q19(a)-(h).

83. Q19(a)-(h) ( $n=92)$. Because this question asked the rule drafters about which factors affect which deference regime applies, the number of respondents considered and percentage calculation in Table 1 exclude the seventeen respondents who indicated they did not know.

84. Q19(a)-(b), (d) $(n=92)$.

85. Q19(e)-(h) (n=92). 
Table 1. Which Factors Affect Whether Chevron Deference Applies to Agency's Interpretation of Ambiguous Statute It Administers?

\begin{tabular}{|l|c|}
\hline Congress Authorized Agency Rulemaking or Formal Adjudication & $84 \%$ \\
\hline Agency Interpretation Made by Rulemaking or Formal Adjudication & $80 \%$ \\
\hline Agency Expertise Relevant to Statutory Provision at Issue & $79 \%$ \\
\hline Agency Interpretation Sets Forth Bounds of Agency's Jurisdiction & $46 \%$ \\
\hline Agency Interpretation Is Longstanding & $43 \%$ \\
\hline Agency Interpretation Is Contemporaneous & $20 \%$ \\
\hline Agency Interpretation Furthers Uniform Administration of Federal Law & $18 \%$ \\
\hline Agency Is Politically Accountable for Its Interpretation & $9 \%$ \\
\hline
\end{tabular}

In other words, the Mead doctrine was one of the most understood among the interpretive tools tested in this study. Only Chevron (at 90 percent), the whole-act rule (at 89 percent), and the ordinary meaning canon (at 87 percent) were reported by more rule drafters as playing a role in their ruledrafting decisions. ${ }^{86}$ At first blush, one may conclude that these findings on Mead support the deference lottery theory as they demonstrate the rule drafters' prerequisite knowledge about the deference doctrines. But perhaps the opposite is true after City of Arlington v. FCC. ${ }^{87}$ Because City of Arlington appears to guarantee that Chevron applies if these two factors are present ${ }^{88}$ and the rule drafters surveyed understood these two factors to be most important, there is far less uncertainty in the first stage of the lottery. There would no longer be a meaningful compound lottery, just a one-stage lottery under Chevron (or Skidmore). To be sure, the survey population here consists of rule drafters, not other types of agency officials who may more often advance agency statutory interpretation through less formal means not addressed by City of Arlington where the first-stage lottery would still be meaningful. Moreover, as discussed in Part II.C, there remains some uncertainty even here, as the rule drafters surveyed indicated that not all ambiguities are created equal.

\section{Scope of Delegation: Not All Ambiguities Are the Same}

A somewhat related issue for determining the effect the deference lottery (or Chevmore codification) may have on agency interpretive practices is whether the agency rule drafters agree with the courts about which types of ambiguities in statutes Congress intends for the agency to fill. After all, if rule drafters understand which ambiguities are owed Chevron space, Skidmore weight, or no deference at all, that could influence whether modifying the deference standard would affect agency behavior. Similarly, if rule drafters already believe certain ambiguities do not trigger Chevron

86. Walker, Inside Agency Interpretation, supra note 7, at 18-20 \& fig.2.

87. 133 S. Ct. 1863 (2013).

88. Id. at 1874 . 
deference, then congressional codification of Skidmore or no deference for those ambiguities (think, e.g., preemption, serious constitutional questions, or major policy questions) arguably would have no effect on agency statutory interpretation.

To assess the rule drafters' understanding about which ambiguities signal delegation, the survey asked about the ten types of ambiguities. Figure 2 presents the findings as to which kinds of ambiguities or gaps the agency rule drafters believed that congressional drafters intend for the federal agencies to fill. ${ }^{89}$

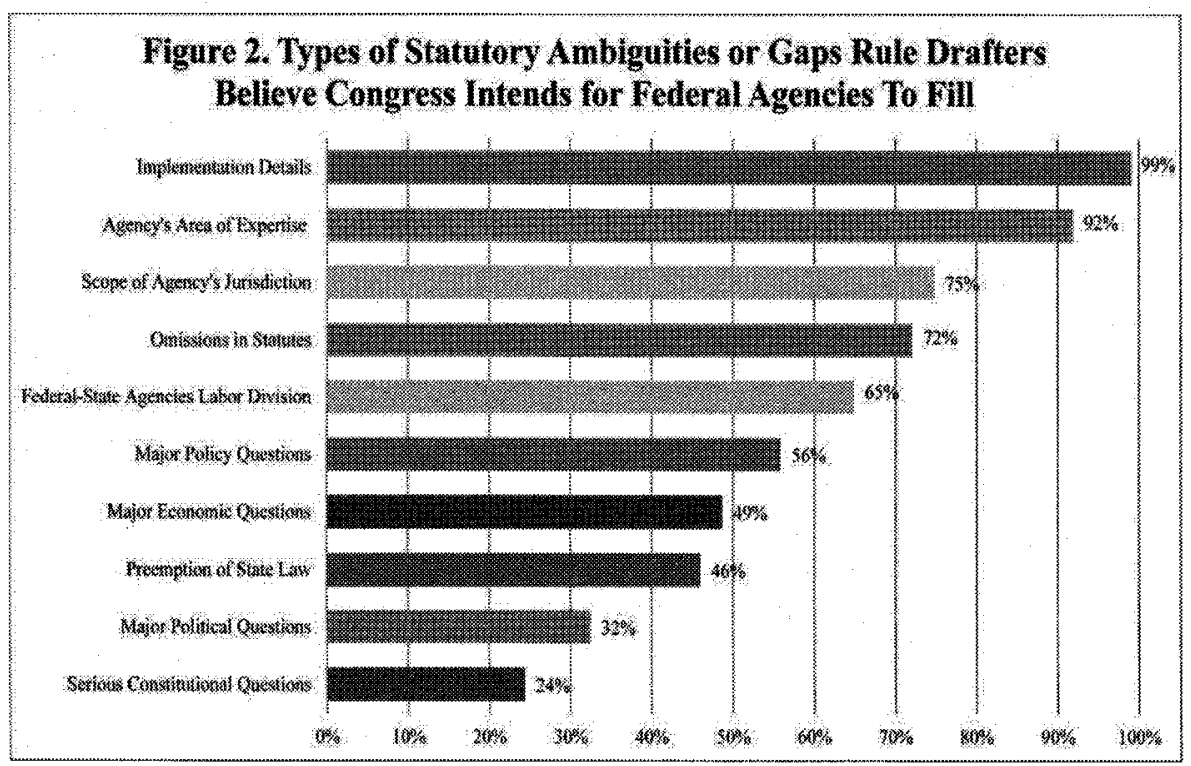

In light of general delegation principles articulated in Chevron and its progeny, three of the top four ambiguities reported as signaling delegation are not too surprising: ambiguities relating to the details of implementation (at 99 percent), the agency's area of expertise (at 92 percent), and omissions in the statute (72 percent). ${ }^{90}$ The only agency rule drafter to dissent on implementation details chose "none of the above," indicating the view that Congress did not intend for agencies to fill any of the types of ambiguities listed. ${ }^{91}$

89. Q15(a)-(j) (n=111). Two respondents indicated they did not know, so the number of respondents considered and percentage calculations in Figure 2 do not include those responses. Another rule drafter indicated none of the above, so that response is included.

90. Q15(a)-(j) $(n=111)$. Nearly two-thirds (65 percent) also indicated that Congress intends to delegate by ambiguity the division between state and federal agencies when both are given implementation roles. That finding has less relevance for this Essay, but it is explored in Part IV.B of Walker, Inside Agency Interpretation, supra note 7.

91. Q15(k) $(\mathrm{n}=111)$. Of the eighteen comments, five expressed concern that the question could not be answered in a general matter but depended on the statute. Q15, cmts. $3,4,6,11 \& 13$. Another criticized it as "indulg[ing] the unsupportable fiction that congressional drafters have a unified approach on these things. They don't." Q15, cmt. 5. 
It is also not too surprising based on existing doctrine that the rule drafters were less confident and more conflicted about whether Congress intends to delegate major questions by ambiguity. The Court has carved out an exception to the Chevron presumption of delegation in the form of the major questions doctrine. Professors Bressman and Gluck nicely frame this doctrine as "a presumption of nondelegation in the face of statutory ambiguity over major policy questions or questions of major political or economic significance." 92 The doctrine exists, as Justice Scalia creatively put it, because it is presumed Congress "does not... hide elephants in mouseholes." 93

The rule drafters were asked about ambiguities or gaps related to the major questions in three ways, with the results as follows: "major policy questions" at 56 percent, "questions of major economic significance" at 49 percent, and "questions of major political significance" at 32 percent. ${ }^{94}$ In other words, far fewer rule drafters indicated that Congress intends to delegate ambiguities implicating major questions than those discussed above concerning implementation details, agency expertise, and statutory omissions. Yet despite Supreme Court guidance to the contrary, a majority indicated that Congress does intend to delegate by ambiguity major policy questions when framed as such - instead of as major economic or political questions. So, there does seem to be some disconnect.

On the other hand, three in four ( 75 percent) rule drafters indicated that Congress intends for agencies to fill gaps or ambiguities relating to the agency's own jurisdiction or regulatory authority. ${ }^{95}$ And in the question about which factors affect whether Chevron deference applies, nearly half (46 percent) indicated that it matters "[w]hether the agency's statutory interpretation sets forth the bounds of the agency's jurisdiction or regulatory authority." 96 While such jurisdictional questions arguably could be viewed as major policy questions, ${ }^{97}$ respondents' views are consistent with City of Arlington, which held that "an agency's interpretation of a statutory ambiguity that concerns the scope of its regulatory authority (that is, its jurisdiction) is entitled to [Chevron] deference." 98

By contrast, only about one in four (24 percent) rule drafters believed that Congress intends for federal agencies to fill gaps implicating serious constitutional questions. ${ }^{99}$ That was the clear loser for this question. And

92. Gluck \& Bressman, Part I, supra note 8, at 1003.

93. Whitman v. Am. Trucking Ass'ns, 531 U.S. 457, 468 (2001); see also Jacob Loshin \& Aaron Nielson, Hiding Nondelegation in Mouseholes, 62 ADMIN. L. REV. 19 (2010) (reviewing literature and providing summary of doctrinal development).

94. Q15(b)-(d) $(\mathrm{n}=111)$.

95. Q15(f) $(\mathrm{n}=111)$.

96. Q19(c) $(\mathrm{n}=109)$. But that question did not ask in what way such factors would affect how Chevron deference applies.

97. See Gluck \& Bressman, Part I, supra note 8, at 1005-06 (so noting); accord Christopher J. Walker, Does Congress Really Mean to Delegate Interpretative Authority to Agencies?, JOTWELL (Aug. 16, 2013), http://adlaw.jotwell.com/does-congress-reallymean-to-delegate-interpretative-authority-to-agencies/.

98. City of Arlington v. FCC, 133 S. Ct. 1863, 1866 (2013).

99. Q15(e) $(\mathrm{n}=111)$. 
that finding challenges at least this author's prior argument that agencies are better positioned than courts to address constitutional questions in statutes they administer in the first instance; thus, perhaps the empirical realities of agency statutory interpretation support the majority view that the constitutional avoidance canon should trump Chevron deference. ${ }^{100}$

Finally, regarding preemption of state law, fewer than half (46 percent) agreed that Congress intends to delegate preemption questions by ambiguity. ${ }^{101}$ This substantial but not overwhelming response is similar to the divide in the scholarly debate and may be due in part to the Supreme Court's failure to date to provide more clarity. ${ }^{102}$ Similarly, roughly half (47 percent) indicated that they use the presumption against preemption when interpreting statutes. 103 These findings cast some doubt on the efficacy of Chevmore codification in the preemption context. If over half of the rule drafters surveyed already do not assume Chevron deference applies to agency preemption decisions - and, indeed, half apply the presumption against preemption when there is an ambiguity - then congressional modification from Chevron space to Skidmore weight would have no effect on agency statutory interpretation at least with respect to those rule drafters. (Such Skidmore codification may, of course, still have an effect on judicial behavior.)

In sum, the vast majority of agency rule drafters surveyed knew of Chevron and Skidmore and indicated that the doctrines played a role in their rule-drafting decisions; they similarly understood the Mead principles for delegation. Many also understood the major questions doctrine but had conflicting views on whether other types of ambiguities signal congressional delegation and thus trigger Chevron deference. If the rule drafters surveyed are representative of the regulatory state generally, then the bureaucrats clearly listen to the courts. And these findings strongly suggest that three decades of Chevron and its accompanying evolution have permeated statutory interpretation inside the regulatory state.

\section{LOOKING FORWARD: THE EFFECT OF JUDICIAL OR LEGISLATIVE MODIFICATION OF THE DEFERENCE DOCTRINES}

That the rule drafters know these deference doctrines and that these doctrines play a role in their rule-drafting decisions only get us halfway to the empirical foundation for the deference lottery and Chevmore codification theories. This part presents the findings as to the second half about how these doctrines may affect agency interpretive practices-i.e., whether the rule drafters think about judicial review standards when

100. See Walker, Brand X Constitutional Avoidance, supra note 19, at 159-61; see also Mashaw, supra note 4, at 508 (noting that "administrators who fail to pursue implementation any time a constitutional issue looms on their horizon could not possibly carry out their legislative mandates effectively").

101. Q15(g) $(\mathrm{n}=111)$.

102. See Gluck \& Bressman, Part I, supra note 8, at $1004 \&$ nn.396-97.

103. Q25(a), (c)-(d) $(\mathrm{n}=99)$. 
drafting rules and interpret a statute differently based on which deference standard applies. This part concludes by looking at other factors that also could influence the effect of judicial or legislative modification of the deference doctrines.

\section{A. The Effect of Judicial Review Standards}

To attempt to test these two empirical assumptions for the deference lottery and Chevmore codification theories, the survey asked whether the rule drafters agreed with seven statements concerning their drafting practices and subsequent judicial review. Figure 3 presents the findings for those questions, ${ }^{104}$ which can be grouped into four sets of observations.

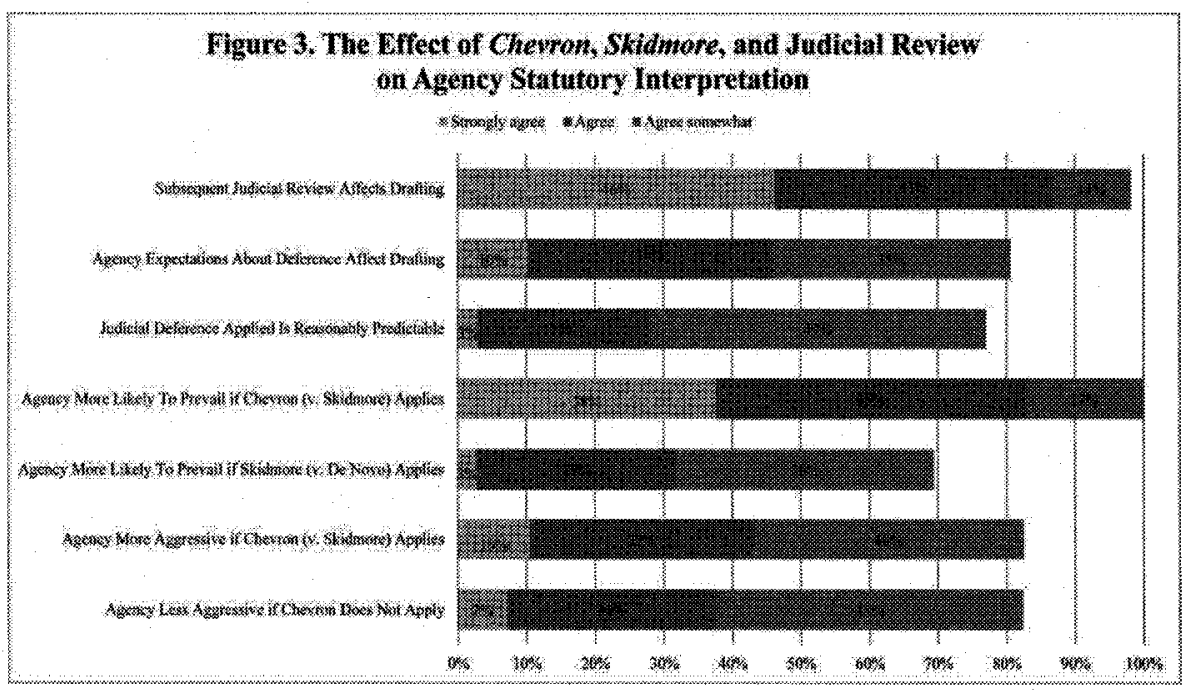

First, nearly nine in ten rule drafters strongly agreed (46 percent) or agreed (41 percent) - and another 11 percent somewhat agreed - that "[w]hen drafting rules and interpreting statutes, agency drafters such as yourself think about subsequent judicial review." 105 This broad agreement is consistent with their responses as to the use of the deference doctrines discussed in Part II and is obviously a prerequisite for the deference lottery and Chevmore codification theories. That said, when asked if "[a]gency expectations about which level of deference (Chevron, Skidmore, no deference, etc.) courts will apply to its statutory interpretation affect the agency's drafting process," only about half strongly agreed (10 percent) or agreed (36 percent), with another third (35 percent) who somewhat

104. Q20(a) (n=106) (nk=0), (b) $(n=100)(n k=7),(c)(n=98)(n k=9),(d)(n=93)(n k=14)$, (e) $(\mathrm{n}=86)(\mathrm{nk}=21),(\mathrm{f})(\mathrm{n}=72)(\mathrm{nk}=35),(\mathrm{g})(\mathrm{n}=85) \quad(\mathrm{nk}=22)$. A varying number of rule drafters indicated that they did not know for particular statements, as reported in the "no knowledge" (nk) number. Accordingly, the number of respondents considered and percentage calculations in Figure 3 do not include those responses.

105. Q20(a) $(\mathrm{n}=106)(\mathrm{nk}=0)$. 
agreed. ${ }^{106}$ In all events, without knowing how judicial review affects their drafting, this does not tell us too much.

Second, only about three in ten strongly agreed ( 3 percent) or agreed ( 25 percent) that "[ $t]$ he level of deference (Chevron, Skidmore, no deference, etc.) that courts apply to a particular agency statutory interpretation is reasonably predictable;" and half (49 percent) somewhat agreed. ${ }^{107}$ In other words, at least among the rule drafters surveyed, these findings cast some doubt - though perhaps not much doubt, as nearly half (49 percent) of rule drafters only agreed "somewhat" and roughly another fourth strongly disagreed (4 percent) or disagreed (19 percent) - on whether there is reasonable uncertainty as would be required at the first stage of the deference lottery. The City of Arlington Court's clarifying opinion may have reduced the level of uncertainty, especially for this particular population (rule drafters) of agency officials. Moreover, reasonable uncertainty has nothing to do with Chevmore codification or judicial modification at the second stage of the deference lottery.

Third, about four in five strongly agreed (38 percent) or agreed (45 percent)-and another 17 percent somewhat agreed-that "[i]f Chevron deference (as opposed to Skidmore deference or no deference) applies to an agency's interpretation of an ambiguous statute it administers, the agency is more likely to prevail in court."108 Relatedly, when asked the same thing about Skidmore deference versus no deference, only one third strongly agreed ( 3 percent) or agreed ( 29 percent) with another 38 percent who somewhat agreed. 109 In other words, the rule drafters surveyed provided strong support for the critical assumption of the deference lottery and Chevmore codification theories that agencies know that the likelihood of success in court is greater if Chevron applies.

Fourth, two questions attempted, perhaps unartfully, to test the final empirical foundation necessary for either theory - that federal agencies are more aggressive in their interpretive efforts if they know Chevron deference will apply. The results were roughly the same whether the question was posed as being more aggressive if Chevron applies or less aggressive if Chevron does not:

- "If the agency knows or strongly believes that Chevron deference (as opposed to Skidmore deference or no deference) will apply to a particular agency interpretation, the agency will be more willing to advance a more aggressive interpretation.": about two in five strongly agreed ( 10 percent) or agreed ( 33 percent), and another 40 percent somewhat agreed; 110 and

106. $\mathrm{Q} 20(\mathrm{c})(\mathrm{n}=98)(\mathrm{nk}=9)$.

107. Q20(b) $(\mathrm{n}=100)(\mathrm{nk}=7)$.

108. $\mathrm{Q} 20(\mathrm{~d})(\mathrm{n}=93)(\mathrm{nk}=14)$.

109. $\mathrm{Q} 20(\mathrm{~d})(\mathrm{n}=72)(\mathrm{nk}=35)$. This number does not reflect the fact that thirty-five of the 107 respondents (33 percent) to this question indicated they did not know the answer compared to only fourteen (13 percent) for the Chevron question. Cf. Q19(d) ( $\mathrm{n}=93)$ (nk=14).

110. $\mathrm{Q} 20(\mathrm{e})(\mathrm{n}=86)(\mathrm{nk}=21)$. 
- "If the agency knows or strongly believes that Chevron deference will not apply to a particular agency interpretation, the agency will be less willing to advance a more aggressive interpretation.": about two in five strongly agreed ( 7 percent) or agreed (31 percent), and another 45 percent somewhat agreed. ${ }^{111}$

Although not as overwhelming as many of the other findings, this two-infive bottom line (38 to 43 percent) - which becomes an even more impressive four-in-five number ( 82 to 83 percent) if those who "somewhat agreed" are included-provides some support for the empirical assumption that federal agencies draft differently when they know Chevron deference applies. In other words, if Congress or the courts were to strip Chevron deference from a particular statutory interpretation, a fair number of the rule drafters surveyed seemed to agree that their agencies would be less aggressive in their interpretive practices.

There are, of course, a number of factors that caution against too much enthusiasm. For instance, neither formulation of the question garnered a majority of "strongly agree" or "agree" votes, with "agree somewhat" being the predominant answer. Similarly, these numbers do not take into account the substantial number of rule drafters who indicated that they did not know the answer-21 of the 107 total respondents (20 percent) for the first question and 22 of the 107 total respondents (21 percent) for the second. These cautions are in addition to those methodological limitations addressed in Part I.B in that the numbers are reported purely descriptively without attempting to generalize beyond the rule drafters surveyed.

Moreover, some of the comments rule drafters volunteered further suggest caution. For instance, one rule drafter remarked: "I think policymakers choose the policy that they believe is best, without being very influenced by the likelihood of prevailing in court, partly taking into account other factors, like likelihood of challenge."112 Another similarly noted that "[l]egal risk is considered by decision-makers, but the policy outcomes generally outweigh the legal risks, particularly any legal niceties related to Chevron v. Skidmore deference."113 In other words, the judicial deference standard is just one of many factors that affect agency statutory interpretation, and it may be a pretty insignificant factor in the large scheme. And a couple rule drafters indicated that they had never personally taken into account or observed others taking into account the type of deference the agency expected to receive. ${ }^{114}$

On the other hand, for at least two reasons these numbers may underrepresent the influence of such modification of agency statutory

111. $\mathrm{Q} 20(\mathrm{~g})(\mathrm{n}=85)(\mathrm{nk}=22)$.

112. Q20, cmt. 4.

113. Q20, cmt. 5 .

114. Q20, cmt. 9 ("My experience involves no case where the agency calibrated its interpretation of a statute according to the type of deference it expected to receive, e.g., Chevron v. Skidmore."); Q20, cmt. 10 ("In the time I've been writing regulations, no one has ever specifically discussed Chevron or Skidmore deference in my hearing. So as far as I see, it's not that relevant."). 
interpretation. First, because all respondents were career civil servants (as opposed to political appointees), they may not have wanted to confess to being more "aggressive" in statutory interpretation based on whether they thought they would prevail in subsequent litigation-reflecting self- or other-deception social desirability bias. ${ }^{115}$ The survey was designed to mitigate the effect of such biases. As for other-deception, the survey was anonymous and administered online outside the presence of a supervisor or peers. As for self-deception, the questions discussed in Part III were asked as to what federal agency rule drafters generally would do, not what the respondent personally would do. Similarly, as discussed, this particular question was asked in two ways-i.e., whether a federal agency would be less willing or more willing to advance an aggressive interpretation based on whether Chevron applies. Although the survey design may mitigate some social desirability bias, it likely does not eliminate it, thus suggesting that the respondents may have understated the effect Chevron deference has on agency interpretive practices.

Second, these questions on interpretive aggressiveness may be above the respondents' pay grade. Perhaps that type of policymaking activity is reserved for the political appointees who were not surveyed. Again, however, the questions asked whether federal agencies-not the respondents personally-would be less or more aggressive, and, as discussed in Part II.B, the rule drafters surveyed have many years of extensive experience inside the regulatory state. Civil servants may not be privy to all decision making at their agencies, but surely they likely are aware of some of it with respect to interpretive efforts. In other words, it may be a conservative understatement in reporting that two in five agreed or strongly agreed-and another two in five agreed somewhat-that federal agencies are more aggressive when Chevron applies.

So where does that leave us with respect to the deference lottery and Chevmore codification hypothesis that modifying the deference standard would affect how aggressive an agency may be in statutory interpretation? The study's findings provide strong support that agency rule drafters think about judicial review when drafting statutes and understand Chevron and Skidmore and how their chances in court are better under Chevron. Many rule drafters also reported that federal agencies advance more aggressive statutory interpretations if they know Chevron applies. But broader generalizations about whether agencies draft more aggressively when they know Chevron applies probably cannot be drawn from this study, based on the responses given and the methodological limitations inherent in the study. Notwithstanding, the findings uncovered should encourage deeper empirical inquiry.

115. For further discussion on social desirability bias, see supra note 68 ; Nederhof, supra note 68; Sackeim \& Gur, supra note 68. 


\section{B. The Effect of Repeated-Game Factors}

Regarding the potential effect of judicial or legislative modification of the deference standards, one of the comments a rule drafter volunteered merits mention: "Whether Chevron deference will apply is only one of many factors that goes into an Agency's decision to take a more aggressive stance."116 Indeed, as the author has more fully explored elsewhere, the predictive effect of modifying the deference lottery may be frustrated by the fact that "agencies in the modern administrative state do not face a win-orgo-home contest when playing the lottery. Instead, it is a repeated gameindeed, a dialogue between courts and agencies-where agencies have multiple opportunities to play again (and win)."117 For similar reasons, the repeated nature of this game may also mitigate the effect of Chevmore codification.

Accordingly, the rule drafters were asked about three additional doctrines that allow agencies to replay the lottery in the event that they lose the first time:

- Brand X (a prior judicial interpretation does.not always trump an agency's subsequent and different interpretation of an ambiguous statute); ${ }^{118}$

- Ventura Ordinary Remand Rule (when a court finds an agency's decision is incorrect, absent exceptional circumstances, the matter should be remanded to the agency for further proceedings); $;^{119}$ and

- Governmental Inter-Circuit Nonacquiescence (a ruling by one circuit does not force the agency to abandon its interpretation in other circuits). ${ }^{120}$

Figure 4 presents the findings from these questions. ${ }^{121}$

116. Q20, cmt. 1.

117. Walker, supra note 10 , at 74 (footnote omitted).

118. Nat'l Cable \& Telecomms. Ass'n v. Brand X Internet Servs., 545 U.S. 967, 982 (2005). The author explores the implications of Brand $X$ on the role of constitutional avoidance under Chevron in Walker, Brand X Constitutional Avoidance, supra note 19, at $156-82$.

119. INS v. Orlando Ventura, 537 U.S. 12, 17 (2002) (per curiam) (describing it as "the law's ordinary remand requirement"). The author traces the evolution of administrative law's ordinary remand rule in Part I of Walker, The Ordinary Remand Rule, supra note 19.

120. See Walker, supra note 10 , at $85-87$ (reviewing literature and discussing this doctrine in context of deference lottery).

121. Q22(a)-(c) $(\mathrm{n}=99) ; \mathrm{Q} 23(\mathrm{a})-(\mathrm{c})(\mathrm{n}=99)$. 


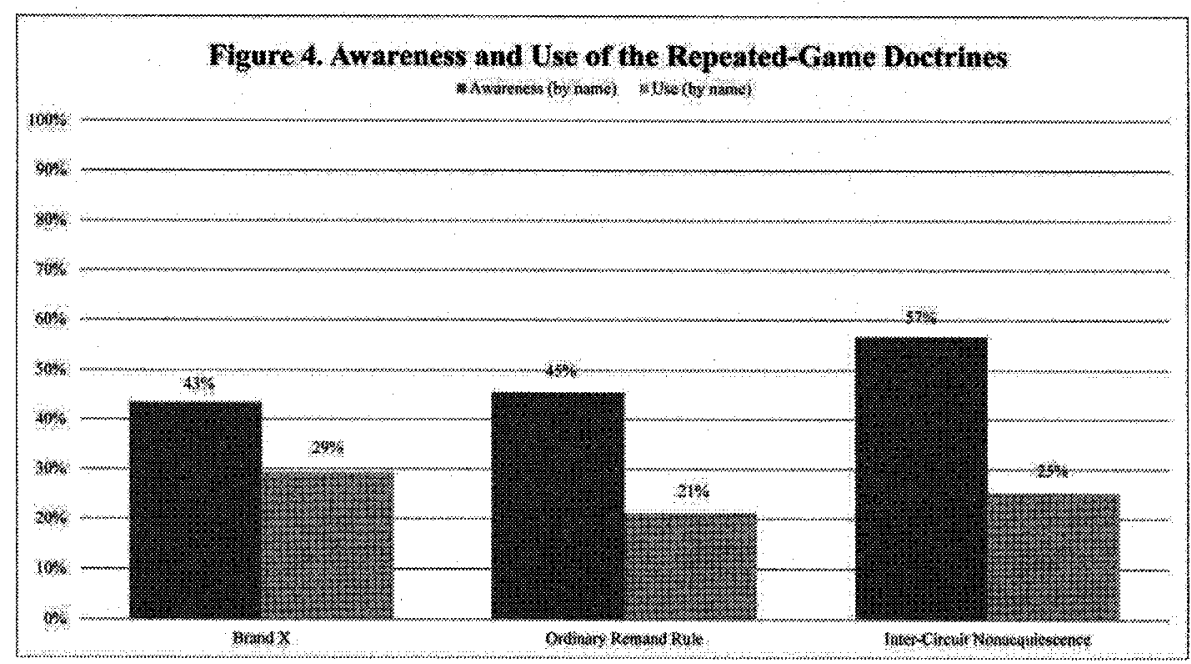

With respect to these repeated-game factors, about one in four (24 percent) rule drafters indicated they did not know any of them, and nearly three in five ( 57 percent) indicated none plays a role in their drafting decisions. Governmental inter-circuit nonacquiescence was the most known at 57 percent, followed by the remand rule at 45 percent and Brand $X$ at 43 percent. By contrast, the doctrine that played a role among most rule drafters was Brand $X$ at 29 percent, followed by nonacquiescence at 25 percent and the remand rule at 21 percent. ${ }^{122}$ In sum, these findings do not seem to provide particularly compelling evidence to undermine the effect that deference standard modification may have on agency interpretive practices - at least at the agency rule-drafting level.

But these repeated-game factors are not just implicated at the drafting stage. When defending agency interpretations, government litigators undoubtedly know and use these principles. That was at least this author's experience while working on the Civil Appellate Staff at the U.S. Department of Justice (DOJ), which defends federal agencies and their statutory interpretations in a variety of contexts. ${ }^{123}$ Thus, if these doctrines are successfully implemented to save an agency statutory interpretation, the predictive effect of modifying the deference standard would be undermined - regardless whether the agency rule drafters also knew about and used these doctrines when drafting. This point may be reinforced by

122. When asked if they agreed with the Brand $X$ principle (without referring to Brand $X$ by name), a strong majority agreed ( 39 percent) or strongly agreed ( 25 percent), and another 10 percent agreed somewhat. But one in about four disagreed ( 21 percent) or strongly disagreed (5 percent). Q16(c) $(n=102)$. One rule drafter commented that whether an agency may choose a different construction "depends on the circumstances. A court's interpretation could make it difficult to have a different interpretation." Q16, cmt. 2.

123. For a helpful description of the DOJ's appellate staffs, see Al Daniel, The Role of DOJ's Appellate Staffs in the Supreme Court and in the Courts of Appeals, SCOTUSBLOG (Dec. 12, 2012), http://www.scotusblog.com/2012/12/the-role-of-dojs-appellate-staffs-inthe-supreme-court-and-in-the-courts-of-appeals/. 
the fact that agency rule drafters and litigators are often not closely connected. One rule drafter observed:

$[\mathrm{M}]$ ost rule drafters and attorneys that practice admin law in government do not handle the litigation associated with rules. I think that is kicked to DOJ, so I definitely think there is a big disconnect between drafters and litigators/those who are defending the rule in court. We often don't talk to each other until the rule is challenged. There is a lot we can learn from the litigators, ways we can be more proactive in rulemaking rather than defensive after the fac[t]..$^{124}$

Accordingly, to fully understand how the repeated-game nature of agency statutory interpretation may temper the effect of judicial or legislative modification of the deference standards, much more empirical investigation needs to be done. And these are just three of the many factors other than the deference standard that could affect how aggressive agencies are in their interpretive efforts.

\section{CONCLUSION}

After thirty years of Chevron, we finally have at least a partial view of its effect inside the regulatory state. The findings uncovered in this stidy arguably confirm common intuition: similar to how Chevron has become one of the most well-known interpretive tools used by courts, litigants, and even congressional drafters, ${ }^{125}$ the agency rule drafters surveyed indicated that Chevron is the most known and most reported as playing a role in their rule-drafting decisions of all twenty-two interpretive tools included in the empirical study. And Mead and Skidmore are not too far behind. Moreover, the rule drafters provided some support for the intuition that federal agencies are more aggressive in their interpretive practices if they know Chevron applies.

But this Essay also underscores how much more work needs to be done to understand how the deference standards affect agency statutory interpretation and, in particular, whether federal agencies are more aggressive in their interpretive efforts if they know Chevron applies. Fortunately, with the advent of Chevmore codification, empirically assessing Chevron's effect on agency statutory interpretation should become somewhat easier. Instead of surveying agency rule drafters about their perceived practices and hoping their answers are not too distorted by self- or other-deception biases, we may now have a natural experiment between those areas where Congress expressly says Chevron does not apply (e.g., OCC preemption) and those where Chevron clearly still does.

This is not just an academic exercise. After all, Chevron and related doctrines attempt to strike a proper separation of powers balance between the branches of government by patrolling the delegation of authority from the principal (Congress) to its unelected agents in the regulatory state.

124. Q20, cmt. 5.

125. Gluck \& Bressman, Part I, supra note 8, at 928 fig.2 (listing Chevron deference as the interpretive tool reported as most used by the congressional drafters surveyed). 
Whether the deference standards help to faithfully control lawmaking by regulation goes to the democratic (and perhaps constitutional) legitimacy of the modern administrative state. ${ }^{126}$ Hopefully it will not take another thirty years to have an even richer understanding of agency statutory interpretation.

126. This legitimacy point is explored in greater detail in Walker, Inside Agency Interpretation, supra note 7; see also Bressman \& Gluck, Part II, supra note 8, at 801 (concluding that "[i]f the democratic legitimacy of courts rests on at least a partial dialogue with Congress, then we need more study not only of Congress, but also of agencies and lobbyists' interpretive practices"); Mashaw, supra note 4, at 537 ("Inquiry into the empirical realities of agency interpretive practice can provide ... an essential step in the assessment of the legitimacy of administrative governance."). 


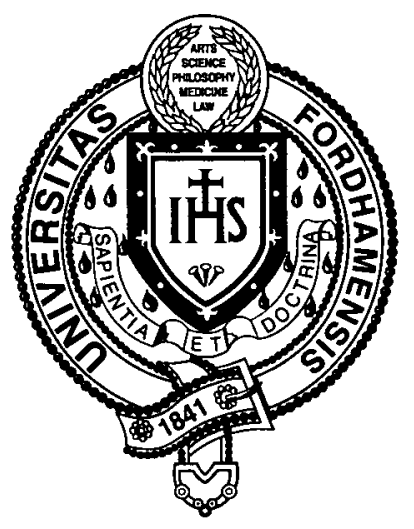

